\title{
Інтраопераційний стан гемокоагуляційної системи крові в паціентів із віддаленими ускладненнями операційного лікування атеросклеротичної оклюзії аорто/клубово-стегнової зони
}

\begin{abstract}
Мета роботи: патогенетично обгрунтувати тромбопрофілактику при оперційних втручаннях у пацієнтів із рецидивом хронічної артеріальної недостатності та пізнім тромбозом бранші аорто/клубово-біфеморального алопротеза і тромбозом клубовостегнового сегмента контрлатеральної нижньої кінцівки.

Матеріали і методи. Прослідковано протягом 2006-2019 рр. віддалені результати хірургічного лікування 522 пацієнтів, з яких у 353 (67,62 \%) було діагностовано двобічну атеросклеротичну оклюзію аорто-стегнової зони та у 159 (30,46 \%) - однобічну оклюзію клубово-стегнової зони.

У дослідженні виділено дві групи пацієнтів: I група - 81 пацієнт із рецидивом хронічної артеріальної недостатності, з яких у 32 (39,63 \%) - ХАН ІІБ ст., у 49 (60,49 \%) - ХАН ІІІА ст.; ІІ група - 47 пацієнтів, з яких у 38 (80,85 \%) діагностований пізній тромбоз бранші аорто/клубово-біфеморального алопротеза і 9 (19,17 \%) - тромбозом клубово-стегнового сегмента контрлатеральної нижньої кінцівки.

У пацієнтів проводилось визначення стану згортальної та фібринолітичної систем.

Результати досліджень та їх обговорення. В результаті досліджень гемокоагуляційної системи пацієнтів із рецидивом хронічної артеріальної ішемії та післяопераційним тромбозом бранші алопротезу і тромбозом клубово-стегнового сегмента контрлатеральної нижньої кінцівки можна стверджувати, що згортальна ланка гемокоагуляції на доопераційному етапі знаходиться в активованому стані. Реваскуляризація супроводжується посиленням активності гіперкоагулятивних та агрегаційних властивостей системи крові, в більшому ступені це виражено у пацієнтів II групи. Гіперкоагуляція на інтраопераційному етапі хірургічного втручання формується за рахунок зростаючого вмісту в крові фібрин-тромбінової фракції гемокоагулятивного каскаду, яка сприяє формуванню фібриногену.

Ірунтуючись на отриманих результатах дослідження системи гемокоагуляції, запропоновано схеми проведення тромбопрофілактики у пацієнтів із атеросклеротичним ураженням аорти та магістральних артерій нижніх кінцівок при реконструктивних операціях.
\end{abstract}

Ключові слова: облітеруючий атеросклероз; реконструктивна операція; рецидив хронічної артеріальної ішемії; тромбоз алопротеза.

Постановка проблеми і аналіз останніх досліджень та публікацій. Оклюзивно-стенотичне ураження артеріального русла нижніх кінцівок складають більше 20 \% всіх проявів патології системи кровообігу [6]. Частота його поширення збільшується до 12 \% у осіб старших вікових груп і майже $31 \%$ із них у перші $5-6$ років захворювання піддають операційному лікуванню [7]. Незважаючи на застосування новітніх лікарських засобів, впровадження нових методів і матеріалів для судинних реконструкцій, частота порушень прохідності сегмента реконструкції залишається високою [9]. Ускладнення пізнього післяопераційного періоду спостерігаються у 7,9 - 34,1 \% пацієнтів [4]. До найбільш частих ускладнень віддаленого післяопераційного періоду відносять тромбози артерій та шунтів, несправжні аневризми анастомозів, інфекційні ускладнення із поширенням процесу на судинні експлантати [3]. В ряді спостережень через 3-5 років після реваскуляризуючої операції діагностують наростання хронічної артеріальної недостатності [1]. Найчастіше ускладнення пізнього післяопераційного періоду розвиваються у пацієнтів, яким було виконано багатоповерхову реконструкцію артеріального русла нижньої кінцівки або ж оперовані в умовах хронічної ішемії, що загрожує кінцівці $[5,8]$. Всі наведені вище ускладнення пізнього післяопераційного періоду вимагають проведення повторного операційного втручання. Результат останніх залежить від ряду обставин, а стан гемокоагуляційної системи крові впливає на виконання повторного хірургічного втручання, а також на отримання задовільного результату повторної реконструкції.

Мета роботи: патогенетично обгрунтувати тромбопрофілактику при операційних втручаннях у пацієнтів із рецидивом хронічної артеріальної недостатності та пізнім тромбозом бранші аорто/клубово-біфеморального алопротеза і тромбозом клубово-стегнового сегмента контрлатеральної нижньої кінцівки.

Матеріали і методи. Прослідковано протягом 2006-2019 рр. віддалені результати хірургічного лікування 522 пацієнтів, 3 яких у 353 
(67,62 \%) було діагностовано двобічну атеросклеротичну оклюзію аорто-стегнової зони та у 159 (30,46 \%) - однобічну оклюзію клубово-стегнової зони. У віддаленому післяопераційному періоді у $146(27,97 \%)$ пацієнтів виявлено розвиток пізніх ускладнень. Серед них у 5 (3,42 \%) випадках - інфаркт міокарда, у 2 (1,38 \%) - гострі порушення мозкового кровобігу та у 139 (95,10 \%) - ускладнення аорто/клубово-стегнової зони. 3 останніх у 38 (27,40 \%) пацієнтів діагностовано пізній тромбоз бранші аорто/клубово-біфеморального алопротеза, у 9 (6,47 \%) - тромбоз клубово-стегнового сегмента контрлатеральної нижньої кінцівки, у 5 (3,59 \%) пацієнтів виявлено несправжні аневризми дистального та проксимального анастомозів аорто/клубово-біфеморального алошунта, у 81 (58,27 \%) - рецидив хронічної артеріальної ішемії нижніх кінцівок (ХАН ІІБ-ІІІА ст. за класифікацією Fontaine R. з врахуванням критеріїв Європейської робочої групи (1992)), у 6 (4,32 \%) - пізні інфекційні ускладнення у вигляді нориці ділянки дистального анастомозу.

У дослідження виділено дві групи пацієнтів: I група - 81 пацієнт із рецидивом хронічної артеріальної недостатності, з яких у 32 (39,63 \%) ХАН ІІБ ст., у 49 (60,49 \%) - ХАН IIIA ст.; II група - 47 пацієнтів, з яких у 38 (80,85 \%) діагностований пізній тромбоз бранші аорто/клубово-біфеморального алопротеза і 9 (19,17 \%) - тромбоз клубово-стегнового сегмента контрлатеральної нижньої кінцівки.

Визначення показників гемокоагуляційної системи здійснювали наступним чином: фібриноген (ФГ) - ваговою методикою: гравіметричним методом за Р. А. Рутбергом (1964); активність фібринстабілізуючого фактора (ФСФ) - за допомогою “набору для визначення фактора ХІІІ” науково-виробничої фірми “SIMKO Ltd” (Львів); тромбопластичну активність крові (ТПА) - за методом Б. А. Кудряшова и П. Д. Улитиной; час рекальцифікації плазми (ЧРП) - за методом Бергергоф і Рока; плазмін (ПЛ), плазміноген (ПГ), сумарну фібринолітичну активність (СФА) - за методом В. А. Монастирського та співавт. (1988); час лізису еуглобінових згустків (ЧЛЕЗ) - застосувуючи "Набір для визначення фібринолітичної активності плазми крові” наукововиробничої фірми “SIMKO Ltd” (Львів); дослідження агрегаційних властивостей тромбоцитів вивчали із застосуванням АДФ у концентрації 2,5 мкмоль/л із записом агрегатограм на аналізаторі AP 2110 "Сoлар”; час лізису еуглобінових згустків (ЧЛЕЗ) - застосувавши "Набір для визначення фібринолітичної активності плазми крові” науково-виробничої фірми “SIMKO Ltd” (Львів).
Результати досліджень та їх обговорення. Обстеженню піддано (I група) 81 пацієнт із рецидивом хронічної артеріальної недостатності (РХАН), з яких у 32 (39,63 \%) випадках встановлено ХАН ІІБ ст., у 49 (60,49 \%) - ХАН IIIА ст. На доопераційному етапі у пацієнтів із РХАН встановлено, що рівень згортальної системи крові вищий, ніж у осіб зі схожою супутньою патологією, однією віковою категорією без клінічних проявів атеросклеротичного ураження артеріального русла нижні кінцівок. Так, у них вміст фібриногену сягав рівня у $(4,76 \pm 0,35)$ г/л (контроль $(3,75 \pm 0,39)$ г/л). Вміст в крові РКМФ знаходився в межах $(0,56 \pm 0,09)$ од. екстр. (контроль $-(0,47 \pm$ $0,05)$ од. екстр.). У вказаній групі відмічено зростання вмісту в крові ФПА до $(2,45 \pm 0,37)$ нг/мл (контроль - $(1,92 \pm 0,38)$ нг/мл; р < 0,05). Одночасно виявлено підвищений рівень ПДФ до (7,42 \pm $2,41)$ мкг/мл (норма $(4,81 \pm 1,67)$ мкг/мл; р < 0,05). Все це відбувається на фоні мінімальних змін зі сторони вмісту в крові ФАК і незначного зниження рівня АТ ІІІ та недостовірного зростання часу ЧРП.

Операційне втручання на магістральних артеріях сприяє активації системи гемостазу. Так, на травматичному етапі встановлено зростання вмісту фібриногену до рівня $(5,24 \pm 0,27)$ г/л (доопераційний - (4,76 \pm 0,35) г/л; $\mathrm{p}<0,05)$. Одночасно відмічено підвищення вмісту РКМФ до $(0,71 \pm 0,09)$ од. екст. $(\mathrm{p}<0,05)$ та зростання рівня в крові ФПА до $(3,87 \pm$ $0,43)$ нг/мл $(\mathrm{p}<0,05)$. Все це відбувається на фоні посиленої до межі $(12,43 \pm 2,48)$ мкг/мл $(\mathrm{p}<0,05)$ ПДФ і незначному зниженні до рівня $(93,41 \pm$ 8,53) \% АТ III. Одночасно спостерігається помірне зниження до рівня $(48,64 \pm 5,34) \%$ ФАК на фоні прискореного у 1,3 раза (р < 0,05) часу рекальцифікації плазми (табл. 1).

На 3 год раннього післяопераційного періоду спостерігали значне (в 1,4 - 2,8 раза ( $<0,05$ $0,001)$ ) зростання всіх складових згортальної системи крові. Впродовж наступних годин раннього післяопераційного періоду не спостерігається суттєвих змін активності системи гемостазу і на 24 год остання залишається на рівні, яка була відмічена на 3 год поопераційного періоду.

Щодо фібринолітичної системи крові пацієнтів із РХАН, то в продовж оперативного втручання та протягом перших 24 год раннього післяопераційного періоду спостерігалась незначна її активація.

Операційне втручання проявляло вплив на агрегаційний стан крові пацієнтів із РХАН. При цьому спостерігали тенденцію до зниження кількості тромбоцитів у крові, яка не досягала достовірних значень протягом усіх етапів хірургічного процесу. 
Таблиця 1. Інтраопераційний стан гемостазу в пацієнтів із рецидивом хронічної артеріальної недостатності

\begin{tabular}{||l|c|c|c|c|c||}
\hline \multicolumn{1}{|c|}{ Показник } & До операції & $\begin{array}{c}\text { Травматичний } \\
\text { етап }\end{array}$ & $\begin{array}{c}3 \text { год після } \\
\text { операції }\end{array}$ & $\begin{array}{c}6 \text { год після } \\
\text { операції }\end{array}$ & $\begin{array}{c}24 \text { год після } \\
\text { операції }\end{array}$ \\
\hline Фібриноген, г/л & $4,76 \pm 0,35$ & $5,24 \pm 0,27 *$ & $5,32 \pm 0,34 *$ & $5,33 \pm 0,39 *$ & $5,27 \pm 0,46 *$ \\
\hline $\begin{array}{l}\text { Розчинні комплекси } \\
\text { мономерів фібрину } \\
\text { (РКМФ), од. екст. }\end{array}$ & $0,56 \pm 0,09$ & $0,71 \pm 0,09 *$ & $1,10 \pm 0,19 * *$ & $0,92 \pm 0,22 *$ & $0,73 \pm 0,24 *$ \\
\hline $\begin{array}{l}\text { Фібринопептид А } \\
\text { (ФПА), нг/мл }\end{array}$ & $2,56 \pm 0,37$ & $3,87 \pm 0,43^{*}$ & $7,04 \pm 0,46 * *$ & $5,41 \pm 0,45^{*}$ & $3,35 \pm 0,47 *$ \\
\hline $\begin{array}{l}\text { Продукт деградації } \\
\text { фібрину (ПДФ), мкг/мл }\end{array}$ & $71,48 \pm 2,41$ & $2,43 \pm 2,48 *$ & $34,36 \pm 5,66 * *$ & $32,07 \pm 5,67 * *$ & $15,57 \pm 4,58 *$ \\
\hline $\begin{array}{l}\text { Фібринолітична } \\
\text { активність крові } \\
\text { (ФАК), \% }\end{array}$ & $53,74 \pm 3,47$ & $48,64 \pm 5,34$ & $45,76 \pm 5,43 *$ & $46,86 \pm 5,52$ & $46,25 \pm 5,24$ \\
\hline $\begin{array}{l}\text { Антитромбін ІІІ } \\
\text { (АТ ІІІ), \% }\end{array}$ & $94,62 \pm 7,38$ & $93,41 \pm 8,53$ & $82,51 \pm 8,64 *$ & $85,52 \pm 8,51 *$ & $86,45 \pm 8,55$ \\
\hline $\begin{array}{l}\text { Час рекальцифікації } \\
\text { плазми (ЧРП), с }\end{array}$ & $112,11 \pm 9,59$ & $96,51 \pm 8,72 *$ & $83,45 \pm 7,58 *$ & $89,81 \pm 8,28 *$ & $94,71 \pm 8,24 *$ \\
\hline \hline
\end{tabular}

Примітки: * - p < 0,05 порівняно з доопераційними значеннями; ** - p < 0,001 порівняно з доопераційними значеннями.

У 1,3 раза (p < 0,05) збільшилася швидкості агрегації тромбоцитів, зростання на 10,24 \% (p < 0,05) ступеня агрегації тромбоцитів та скорочення на $11,18 \%$ (p < 0,05) часу агрегації тромбоцитів.

Вивчення стану гемокоагуляційної системи провели (II група) у 47 пацієнтів, з яких 38 (80,85 \%) діагностований пізній тромбоз бранші аорто/клубово-біфеморального алопротеза (ПТА) і 9 (19,17 \%) із тромбозом клубово-стегнового сегмента контрлатеральної нижньої кінцівки (ТКСНК). Вже на доопераційному етапі у пацієнтів встановлено високий рівень коагулятивної активності крові. Вона перевищувала не тільки показники осіб контрольної групи, але й пацієнтів із РХАН. Вказаний стан згортальної системи крові формувався високим у $(2,65 \pm 0,31)$ нг/мл вмістом ФПА в крові, підвищеним до $(7,89 \pm 2,02)$ мкг/мл рівнем ПДФ в крові, зниженою до $(89,89 \pm 7,86) \%$ активністю антитромбін III, скороченим до $(91,72 \pm 10,19)$ с ЧРП та підвищеним до $(0,67 \pm 0,12)$ од. екст. вмістом в крові РКМФ. При цьому вміст у крові фібриногену знаходився на рівні $(5,56 \pm 0,49)$ г/л, що вище в 1,5 $(\mathrm{p}<0,05)$ раза, ніж у осіб контрольної групи, і в 1,2 $(\mathrm{p}<0,5)$ раза, ніж у пацієнтів із РХАН.

Операційне втручання з приводу ПТА та ТКСНК сприяє активації системи гемостазу (табл. 2). На травматичному етапі не спостерігали суттєвих змін у вмісті в крові фібриногену, але спостерігається значне зростання до $(0,81 \pm 0,11)$ од. екст. $(\mathrm{p}<0,05)$ вмісту в крові РКМФ. Останнє підтверджується зростанням до $(4,54 \pm 0,32)$ нг/мл $(\mathrm{p}<0,05)$ вмісту ФПА. І все це відбувається при посиленній ПДФ до рівня $(13,51 \pm 2,54)$ мкг/мл ( $<0,001)$ і незначному зниженні рівня АТ III до $(82,02 \pm 7,13) \%(\mathrm{p}<0,5)$. Останнє відбувається на фоні помірного зниження рівня до $(42,86 \pm 5,13) \%(\mathrm{p}<0,05)$ ФАК та гальмуванні на $14,8 \%(\mathrm{p}<0,05)$ ЧРП.

Максимальної активності коагулятивна система крові набуває на 6 год раннього післяопераційного періоду. Саме у вказаний період відбулося значне (в $1,9-2,7$ раза $(\mathrm{p}<0,05-0,001))$ зростання всіх складових згортальної системи. В наступні години раннього післяопераційного періоду встановлено незначне зниження напруження гемокоагуляційного гемостазу, але його рівень під кінець першої доби залишається на межі, яка була зафіксована на 3 год раннього післяопераційного періоду.

Реваскуляризація нижніх кінцівок супроводжується змінами стану фібринолітичної системи крові. Так, у пацієнтів на момент травматичного етапу операційного втручання спостерігається підвищення на $12,25 \%(\mathrm{p}<0,05)$ рівня плазміну в крові з одночасним зниженням на 8,65 \% $(\mathrm{p}<0,5)$ рівня плазміногену та зменшенням на 27,45 \% $(\mathrm{p}<0,05)$ сумарної фібринолітичної активності при подовженні на 9,42 \% $(\mathrm{p}<0,05)$ часу лізису еуглобулінових згустків. О 6 год раннього післяопераційного періоду спостерігається підвищення на $28,18 \%(\mathrm{p}<0,05)$ рівня в крові плазміну, що відбувається на фоні попереднього рівня в крові плаз- 
Таблиця 2. Інтраопераційний стан гемостазу в пацієнтів із пізнім тромбозом бранші аортобіреморального алопротеза та тромбозом клубово-стегнового сегмента контрлатеральної нижньої кінцівки

\begin{tabular}{||l|c|c|c|c|c||}
\hline \multicolumn{1}{|c|}{ Показник } & До операції & $\begin{array}{c}\text { Травматичний } \\
\text { етап }\end{array}$ & $\begin{array}{c}\text { 3 год } \\
\text { після операції }\end{array}$ & $\begin{array}{c}6 \text { год } \\
\text { після операції }\end{array}$ & $\begin{array}{c}24 \text { год } \\
\text { після операції }\end{array}$ \\
\hline Фібриноген, г/л & $5,56 \pm 0,49$ & $5,61 \pm 0,59 *$ & $5,64 \pm 0,62 *$ & $6,73 \pm 0,52 *$ & $6,31 \pm 0,59 *$ \\
\hline $\begin{array}{l}\text { Розчинні комплекси } \\
\text { мономерів фібрину } \\
\text { (РКМФ), од. екст. }\end{array}$ & $0,67 \pm 0,12$ & $0,81 \pm 0,11^{*}$ & $1,23 \pm 0,19 * *$ & $1,24 \pm 0,18^{*}$ & $0,97 \pm 0,26 *$ \\
\hline $\begin{array}{l}\text { Фібринопептид А, } \\
\text { нг/мл }\end{array}$ & $2,65 \pm 0,31$ & $4,54 \pm 0,32 *$ & $7,09 \pm 0,53 * *$ & $6,72 \pm 0,56 *$ & $5,11 \pm 0,56^{*}$ \\
\hline $\begin{array}{l}\text { Продукт деградації } \\
\text { фібрину, мкг/мл }\end{array}$ & $7,89 \pm 2,02$ & $13,51 \pm 2,54^{*}$ & $18,33 \pm 5,36 * *$ & $19,44 \pm 5,59 * *$ & $14,58 \pm 5,47 *$ \\
\hline $\begin{array}{l}\text { Фібринолітична } \\
\text { активність крові, \% }\end{array}$ & $54,41 \pm 4,54$ & $42,86 \pm 5,13 *$ & $41,08 \pm 5,51 *$ & $43,72 \pm 5,14 *$ & $44,51 \pm 4,55 *$ \\
\hline Антитромбін ІІІ, \% & $89,89 \pm 7,86$ & $82,02 \pm 7,13^{*}$ & $78,54 \pm 91,04 *$ & $81,35+8,97 *$ & $84,36+8,57$ \\
\hline $\begin{array}{l}\text { Час рекальцифікації } \\
\text { плазми, с }\end{array}$ & $91,78 \pm 10,19$ & $80,17 \pm 8,53 *$ & $79,74 \pm 8,62$ & $84,76 \pm 8,58$ & $88,47 \pm 8,59$ \\
\hline \hline
\end{tabular}

Примітки: * - p < 0,05 порівняно із доопераційними значеннями; ** - p < 0,001 порівняно із доопераційними значеннями.

міногену, підвищення на 17,94 \% $(\mathrm{p}<0,05)$ сумарної фібринолітичної активності та скорочення до рівня доопераційного часу $(167,67 \pm 2,65)$ хв лізису еуглобулінових згустків.

Аналіз результатів дослідження агрегаційного стану крові у пацієнтів із ПТА та ТКСНК дав можливість встановити, що на доопераційному етапі відбувається пришвидшення на 11,63 \% (р < 0,05) ШАТ, підвищення на 7,58 \% САТ та вкорочення на 9,09 \% ЧАТ порівняно із показниками осіб контрольної групи.

Операційне втручання у пацієнтів сприяло зміні агрегаційного стану крові, Так, на 3 год раннього післяопераційного періоду кількісний вміст тромбоцитів знизився на 14,75 \% (р < 0,05) порівняно із доопераційним періодом. Водночас відбулося прискорення в 1,6 раза (р < 0,05) ШАТ, підвищення на 22,13\% (р < 0,05) САТ на фоні вкорочення до $(168,76 \pm 1,51)$ хв $(\mathrm{p}<0,05)$ ЧАТ. Наведені зміни агрегаційного стану крові утримуються до кінця першої доби раннього післяопераційного періоду.

Підсумовуючи отримані результати дослідження гемокоагуляційної системи пацієнтів із PХАН та ПТА і ТКСНК, можна стверджувати, що всі його ланки на доопераційному етапі знаходяться в активному стані. Реваскуляризація супроводжується посиленням гіперкоагулятивних та агрегаційних властивостей системи крові, найбільшою мірою це відбувається у пацієнтів із ПТА i TKCНК. Гіперкоагуляція на інтраопераційному етапі хірургічного втручання формується за раху- нок зростання вмісту в крові фібрин-тромбінової фракції гемокоагулятивного каскаду, яка сприяє формуванню фібриногену. Високому ризику розвитку тромботичного процесу в судинах сприяє низька активність фібринолітичної системи крові. Наведені обставини вказують на загрозу розвитку в ранньому післяопераційному періоді як сегмента реконструкції, так і вен нижніх кінцівок. Останнє вимагає запропонувати патогенетично обгрунтовану тромбопрофілактику при операційних втручаннях у пацієнтів із РХАН та ПТА і ТКСНК.

Встановлено, що операційне втручання супроводжується посиленням гіперкоагулятивних та агрегаційних властивостей системи крові. Слід вказати, що стан гіперкоагуляційної та агрегаційної систем крові у пацієнтів із пізнім тромбозом бранші аорто-біфеморального алопротеза та тромбозом клубово-стегнового сегмента контрлатеральної нижньої кінцівки проявляють вищий ступінь активності порівняно із рівнем гіперкоагуляційної та агрегаційної систем крові у пацієнтів із рецидивом хронічної артеріальної недостатності. Встановлено, що рівень показників згортальної системи поступово зростає протягом операційного втручання, досягаючи максимальних значень на 3 год раннього післяопераційного періоду. Подібне відбувається за рахунок зростання вмісту фібриногену в плазмі крові. Одночасно спостерігається суттєве підвищення рівня розчинних комплексів мономерів фібрину (РКМФ). Поява в крові підвищеного вмісту РКМФ свідчить 
про зростання в ній рівня тромбіну. Підтвердженням вказаного слугує високий вміст в плазмі крові фібринопептиду А та підвищена деградація продукту фібрину. Вказаному процесу сприяє знижена активність фібринолітичної системи крові, пришвидшений час рекальцифікації плазми.

Стан гіперкоагуляції на інтраопераційному етапі хірургічного втручання формується за рахунок зростаючого вмісту в крові фібрин-тромбінової фракції гемокоагулятивного каскаду. Тобто, у вказаний період операційного втручання, попри малопомітну активність інших факторів гемокоагуляційного каскаду, значно активується ІІа фактор зсідальної системи. I тому для попередження розвитку гіперкоагулятивного стану крові і можливого формування тромбозу вже на етапі завершення операційного втручання слід призначати антикоагулянт, який би проявляв цілеспрямовану дію на ІІа фактор. Такими властивостями володіє нефракціонований гепарин (НФГ). Дія НМГ переважно спрямована на Ха фактор гемокоагуляційного каскаду, який у вказаний період проявляє нижчу активність [2].

Отже, 3 вище наведених результатів дослідження спосіб тромбопрофілактики при реконструктивних втручаннях у пацієнтів із РХАН та ПТА і ТКСНК передбачає введення нефракціонованого гепарину, який проявляє переважаючу дію на ІІа фактор (тромбін - фібриноген) гемокоагуляційного каскаду, відразу після закінчення операційного втручання внутрішньовенним шляхом. У зв'язку із збереженням гіперкоагулятивного стану згортальної системи крові у ранньому післяопераційному слід продовжувати призначення НФГ в наступні 7-9 діб (контроль АЧТЧ) післяопераційного періоду.

Можна вибрати іншу схему тромбопрофілактики: призначення НФГ можна припинити на 12 год раннього післяопераційного періоду і розпо- чати тромбопрофілактику НМГ. Останні проявляють переважаючу дію на Ха фактор гемокоагуляційного каскаду. Поєднання НФГ і НМГ дає можливість одночасного впливу на різні фактори згортальної системи і знизити ризик розвитку тромбозу.

Висновоки. 1. 3 травматичного етапу операційного втручання у пацієнтів із рецидивом хронічної артеріальної недостатності та пізнім тромбозом бранші аорто/клубово-біфеморального алопротеза і тромбозом клубово-стегнового сегмента контрлатеральної нижньої кінцівки розпочинається, в основному, за рахунок тромбін-фібринового сегмента зсідальної системи, активації гемокоагуляційної системи і наростання ії рівня до 3 - 6 години раннього післяопераційного періоду. Формування гіперкоагулятивного стану крові відбувається на фоні малоактивної фібринолітичної системи і наростання активності агрегаційного стану крові.

2. Гіперкоагулятивний стан на інтраопераційному етапі хірургічного втручання формується в основному за рахунок тромбін-фібринового сегмента зсідальної системи в результаті значної активності ІІа фактора зсідальної системи при малопомітній активності інших факторів гемокоагуляційного каскаду, тромбопрофілактику слід розпочинати із призначення НФГ, який проявляє переважаючу дію на IІа фактор.

Перспективи подальших досліджень. Недослідженими питаннями залишаються фактори впливу на ступінь активації згортальної системи у віддаленому післяопераційному періоді після проведення реконструктивних втручань на аорті та магістральних артеріях нижніх кінцівок. Вплив на ці фактори дозволить покращити результати реконструктивних операційних втручань.

\section{СПИСОК ЛІТЕРАТУРИ}

1. Белов Ю. В. Повторные реконструктивные операции на аорте и магистральных артериях / Ю. В. Белов, А. Б. Степаненко. - М. : Медицинское информационное агентство, 2009. $-176 \mathrm{c}$.

2. Тромбопрофілактика при оперативному втручанні у пацієнтів із високим ризиком розвитку тромбоемболічних ускладнень / С. Я. Костів, І. К. Венгер, О. І. Зарудна [та ін.] // Науковий вісник Ужгородського університету, серія "Медицина”. - 2014. - Вип. 1 (49). - С. 112-114.

3. Губка В. А. Повторные реконструкции у больных облитерирующим атеросклерозом с отдаленными осложнениями / А. В. Губка // Патология. - 2012. - № 2 (25). - С 43-45.

4. Тактика лечения мультифокального атеросклероза / П. И. Никульников, А. В. Ратушняк, С. Н. Фуркало [та ін.] //

Вісник Української медичної стоматологічної академії. 2015. - Т. 9, № 1. - С. 318-321.

5. Профундопластика при хронічній ішемії нижніх кінцівок / Русин В. І., Корсак В. В., Русин В. В. [та ін.]. - Ужгород : Всеукраїнське державне видавництво “Карпати”, 2018. - 180 с. 6. 30-й Конгресс европейского общества сосудистых хирургов (Копенгаген, Дания, 28-30 сентября 2016) / Калмыков Е. Л., Скрыпник Д. А., Виноградов Р. А., Гаибов А. Д. // Ангтология и сосудистая хирургия. - 2017. - № 1. - С. 143-147.

7. Заболевания периферических артерий: руководство / ред. : Э. Р. Молер, М. Р. Джафф ; пер. с англ. ред. М. В. Писарев. М. : ГЭОТАР-Медиа, 2010. - 224 с.

8. Hallett J. V. Selection and preparation of high-risk patient for repair of abdominal aortic aneurysm / J. V. Hallett, T. C. Bower, K. J. Cher- 
ry // Mayo Clin. Proc. - 2004. - Vol. 69 (6). - P. 763-768.

9. Popliteal artery disease: diagnosis and treatment / L. B. Wright,
W. J. Matechett, C. P. Cruz [et al.] // Radiographicm. - 2008. Vol. 24 (2). - P. 467-479.

\section{REFERENCES}

1. Belov, Yu.P., \& Stepanenko, A.B. (2009). Povtorny rekonstruktivnyie operatsyi na aorte i magistralnykh arteriyakh [Repeat reconstructive operations on the aorta and other large arteries]. Meditsynskoe informatsionnoye agenstvo - Medical Informational Agency, 176 [in Russian].

2. Kostiv, S.Ya., Venger I.K., Zarudna, O.I., Kostiv, O.I., Husak, M.O. (2014). Tromboprofilaktyka pry operatyvnomu vtruchanni u patsiientiv is vysokym ryzykom rozvytku tromboembolichnykh uskladnen [Thromboprophylaxy in surgical treatment of patients with the high risk of venous thromboembolism]. Naukovyi visnyk Uzhhorodskoho universytetu, seriia "Medytsyna” - Uzhhorod University Scientific Bulletin, Section "Medicine", 1 (49), 112-114 [in Ukrainian].

3. Hubka, V.A. (2012) Povtornyie rekonstruktsii u bolnykh obliteriruyushchim aterosklerosom s otdalennymy oslozhneniya$\mathrm{mi}$ [Repeat reconstrucrtions in atherosclerosis obliterans patients with late complications]. Patologiya - Pathology, 2 (25), 43-45 [in Russian].

4. Nikulnikov, P.I., Ratushniak, A.V., Furkalo, S.N., Guch, A.A., Lyskunov, A.V. (2015). Taktika lecheniya multifokalnogo ateroskleroza [Treatment strategy of multifocal atherosclerosis]. Visnyk Ukrainskoi medychnoi stomatolohichnoi akademii - Ukrainian Medical

Stomatological Academy Bulletin, 9 (1), 318-321 [in Russian]. 5. Rusyn, V.I., Korsak, V.V., Rusyn V.V., Horlenko, F.V., Kopolovets, I.I., Mashura, V.V. et al. (2018). Profundoplastyka pry khronichnii ishemii nyzhnikh kintsivok [Profundoplastics in term of the chronic ischemia of the lower extremities]. Uzhhorod: Vseukrainske vydavnytstvo "Karpaty” [in Ukrainian].

6. Kalmykov, E.L., Skrypnik, D.A.,Vinogradov, R.A., Gaibov, A.D. (2017). 30-y kongress yrvropeyskogo obshchestva sosudistykh khirurgov (Kopengagen, Dania, 28-30 sentyabrya 2016g.) [The 30 Congress of the European Society of Vascular Surgeons (Cjptnghagen, Denmark, September 28-30, 2016)]. Angiologiya i Sosud. khirurgiya - Angiology and Vascular Surgery, 143 (1), 47 [in Russian].

7. Moler, E.R., \& Dzhaff, M.R. (Eds.). (2010). Zabolevaniya perinfericheskikh arteriy [Diseases of peripheral arteries]. RF:GEOTAR-Media [in Russian].

8. Hallett, J.V., Bower, T.C., \& Cherry, K.J. (2004) Selection and preparation of high-risk patient for repair of abdominal aortic aneurysm. Mayo Clin. Proc., 69 (6), 763-768.

9. Wright, L.B., Matechett, W.J., Cruz, C.P., James, C.A., Culp, W.C., Edidt, J.F. (2008) Popliteal artery disease: diagnosis and treatment. Radiographicm, 24 (2), 467-479.

Отримано 29.04.2020

\section{INTRAOPERATIVE STATUS OF THE BLOOD HAEMOCOAGULATION SYSTEM IN PATIENTS WITH LONG-TERM COMPLICATIONS OF SURGICAL TREATMENT OF ATHEROSCLEROTIC OCCLUSION OF THE AORTO/ILIAC-FEMORAL ZONE}

The aim of the work: to substantiate thromboprophylaxis at surgical interventions in patients with recurrence of chronic arterial insufficiency and late thrombosis of the aorto/iliac-bifemoral alloprosthesis and thrombosis of the iliac-femoral segment of the contralateral lower extremity.

Materials and Methods. Long-term results of surgical treatment of 522 patients during 2006-2019 were traced. 353 (67.62 \%) patients were diagnosed with bilateral atherosclerotic occlusion of the aorto-femoral zone and 159 (30.46 \%) - unilateral occlusion of the iliacfemoral zone.

Two groups of patients were identified in the study: group I - 81 patients with recurrence of chronic arterial insufficiency: in 32 (39.63 \%) - chronic arterial insufficiency IIB stage, in 49 (60.49 \%) - chronic arterial insufficiency III stage; group II - 47 patients: 38 (80.85 \%) were diagnosed late thrombosis of the aorto/iliac-bifemoral alloprosthesis and 9 (19.17 \%) with thrombosis of the iliacfemoral segment of the contralateral lower extremity.

In patients, the status of coagulation and fibrinolytic systems was determined.

Results and Discussion. As a result of studies of the hemocoagulation system of patients with recurrence of chronic arterial ischemia and postoperative alloprosthesis branch thrombosis and thrombosis of the iliac-femoral segment of the contralateral lower extremity, it is possible to state that the coagualation system is active before operation. Surgery is accompanied by increased coagulation and aggregation properties of the blood system. Hypercoagulation at the intraoperative stage of surgery is formed due to the increasing blood content of the fibrin-thrombin fraction of the hemocoagulative cascade, which contributes to the formation of fibrinogen.

Based on the results of the study of the hemocoagulation system, schemes of thromboprophylaxis in patients with atherosclerotic lesions of the aorta and main arteries of the lower extremities during reconstructive operations were proposed.

Key words: obliterative atherosclerosis; reconstructive surgery; recurrence of chronic arterial ischemia; alloprosthesis thrombosis. 


\author{
И. К. ВЕНГЕР, С. Я. КОСТИВ, М. О. ГУСАК, Д. В. ХВАЛИБОГА, Д. В. КОВАЛЬСКИЙ
}

Тернопольский национальный медицинский университет имени И. Я. Горбачевского МОз Украины

\title{
ИНТРАОПЕРАЦИОННОЕ СОСТОЯНИЕ ГЕМОКОАГУЛЯЦИОННОЙ СИСТЕМЫ КРОВИ У ПАЦИЕНТОВ С ОТДАЛЕННЫМИ ОС.ЛОЖНЕНИЯИ ОПЕРАТИВНОГО ЛЕЧЕНИЯ АТЕРОСКЛЕРОТИЧЕСКОЙ ОККЛЮЗИИ АОРТО/ПОДВЗДОШНО-БЕДРЕННОЙ ЗОНЫ
}

Цель работы: патогенетически обосновать тромбопрофилактику при оперативных вмешательствах у пациентов с рецидивом хронической артериальной недостаточности и поздним тромбозом бранши аорто/ подвздошно-бифеморального аллопротеза и тромбозом подвздошно-бедренного сегмента контралатеральной нижней конечности.

Материалы и методы. Прослежены в течение 2006-2019 гг. отдаленные результаты хирургического лечения 522 пациентов, из которых в 353 (67,62 \%) было диагностировано двустороннюю атеросклеротическою окклюзию аорто-бедренной зоны и в 159 (30,46 \%) - одностороннюю окклюзию подвздошно-бедренной зоны.

В исследовании выделено две группы пациентов: I группа - 81 пациент с рецидивом хронической артериальной недостаточности, из которых у 32 (39,63 \%) - ХАН ІІ Б ст., у 49 (60,49 \%) - ХАН III А ст.; II группа - 47 пациентов, из которых у 38 $(80,85 \%)$ диагностирован поздний тромбоз бранши аорто/подвздошно-бифеморального аллопротеза и у 9 (19,17 \%) - тромбоз подвздошно-бедренного сегмента контралатеральной нижней конечности.

У пациентов проводилось определение состояния свертывающей и фибринолитической систем.

Результаты исследований и их обсуждение. В результате исследований гемокоагуляционной системы пациентов с рецидивом хронической артериальной ишемии и послеоперационным тромбозом бранш аллопротеза и тромбозом подвздошнобедренного сегмента контралатеральной нижней конечности можно утверждать, что свертывающие звено гемокоагуляции на дооперационном этапе находится в активированном состоянии.

Реваскуляризация сопровождается усилением активности гиперкоагуляционной и агрегационной систем крови, в большей степени это выражено у пациентов II группы. Гиперкоагуляция на интраоперационном этапе хирургического вмешательства формируется за счет растущего содержания в крови фибрин-тромбиновой фракции гемокоагулятивного каскада, которая способствует формированию фибриногена. Основываясь на полученных результатах исследования системы гемокоагуляции, предложены схемы проведения тромбопрофилактики у пациентов с атеросклеротическим поражением аорты и магистральных артерий нижних конечностей при реконструктивных операциях.

Ключевые слова: облитерирующий атеросклероз; реконструктивная операция; рецидив хронической артериальной ишемии; тромбоз аллопротеза. 